\title{
Analisis Konsumsi Energi Pada Proses Pemipilan Jagung (Zea Mays L.): Studi Kasus di Kabupaten Padang Pariaman Sumatera Barat
}

\author{
Energy Consumption Analysis of Corn (Zea Mays L.) Shelling Process: Case Study in Padang Pariaman, West \\ Sumatera
}

\author{
Renny Eka Putri ${ }^{1 *}$, Wirna Nepis ${ }^{1}$, Khandra Fahmy $^{1}$ \\ 1Jurusan Teknik Pertanian dan Biosistem Fakultas Teknologi Pertanian, Universitas Andalas, Padang, Indonesia \\ *E-mail: rennyekaputri@ae.unand.ac.id
}

Diterima: 10 Februari 2021; Disetujui: 23 Agustus 2021

\begin{abstract}
ABSTRAK
Padang pariaman merupakan salah satu sentral budidaya jagung yang berlokasi di Provinsi Sumatera Barat. Pemipilan merupakan salah satu faktor penting dalam pasca panen jagung. Tingkat kehilangan hasil yang cukup tinggi pada proses pemipilan membuat teknologi pemipilan berkembang cukup pesat. Beberapa metode pemipilan yang umumnya diaplikasikan oleh masyarakat diantaranya adalah pemipilan secara tradisional, menggunakan alat pemipil sederhana, serta pemipilan secara mekanis. Selain uji teknis alat, analisa energi juga dibutuhkan dalam mengevaluasi alat dan mesin pertanian. Sumber energi input pemipilan jagung meliputi energi manusia, energi mesin dan energi bahan bakar. Tujuan dari penelitian adalah untuk mengevaluasi total konsumsi energi pada proses pemipilan jagung dan uji teknis untuk masing-masing metode pemipilan jagung. Hasil penelitian menunjukkan total konsumsi energi pemipilan secara manual lebih besar dibandingkan dengan alat pemipilan sederhana dan mesin dengan total konsumsi energi pemipilan jagung berturut-turut yaitu sebesar 50,66 $\mathrm{MJ} /$ ton, $282,33 \mathrm{MJ} /$ ton dan $388,66 \mathrm{MJ} /$ ton pada proses pemipilan jagung secara mekanis, alat pemipil sederhana, dan manual. Rata-rata kapasitas pemipilan mekanis, alat pemipil sederhana dan manual sebesar 966,64 kg/jam, 87,93 kg/jam dan 40,65 $\mathrm{kg} / \mathrm{jam}$, dengan rendemen masing-masing 75,41\%; 83,54 \%; dan 82,50 \%, secara berturut-turut. Data total energi dapat digunakan sebagai acuan dalam mendesain alat pemipil jagung yang lebih modern.
\end{abstract}

Kata kunci: kapasitas pemipilan; konsumsi energi: energi manusia; rendemen pemipilan.

\begin{abstract}
Padang Pariaman is one of the centers of corn cultivation locating in West Sumatra Province, Indonesia. Shelling is one of the important factors in corn post-harvest practices. Due to high yield loss rate in corn shelling process, the development of shelling technology has been rapidly increasing recently. The local community normally uses several ways for shelling process, e.g. using traditional sheller, simple corn sheller, and mechanical sheller methods. Beside doing the technical test for the sheller, energy analysis is also needed in evaluating agricultural tools and machinery. Corn shelling input energy is obtained from human, machine and fuel energy. The purpose of the study was to evaluate the total energy consumption of the corn shelling process and technical tests for each corn shelling method. Based on the research, the total energy consumption of shelling manually was greater than the simple and manual shelling tools. The total energy consumption of corn shelling process was $50.66 \mathrm{MJ} /$ ton, $282.33 \mathrm{MJ} /$ ton and $388.66 \mathrm{MJ} /$ ton, respectively. The average mechanical shelling capacity, simple and manual shelling tools were $966.64 \mathrm{~kg} /$ hour, $87.93 \mathrm{~kg} /$ hour and $40.65 \mathrm{~kg} /$ hour, with yields of $75.41 \%, 83.54 \%$ and $82.50 \%$, respectively. Data of energy can be used as a reference in designing modern corn sheller.
\end{abstract}

Keywords: capacity; fuel energy; human energy; machine energy

\section{PENDAHULUAN}

Jagung (Zea mays L.), merupakan tanaman pangan selain beras yang memiliki peran penting di dunia sebagai penghasil karbohidrat. Jagung di masa kini banyak dikonsumsi oleh masyarakat baik secara langsung maupun olahan. Selain itu, jagung juga dapat dimanfaatkan sebagai pakan ternak. Berdasarkan keterangan dari Badan Pusat Statistik (2018), produksi jagung di Sumatera Barat termasuk sepuluh besar di Indonesia yang setiap tahunnya mengalami peningkatan. Produksi jagung tahun 2015 ke tahun 2016 meningkat sebesar $18,086 \%$ dan pada tahun 2017 meningkat menjadi $38,552 \%$ dari tahun sebelumnya. Kabupaten Padang Pariaman merupakan salah satu sentral jagung di Sumatera Barat dengan total produksi rata-rata sebesar 5,5 - 6 ton/ha dengan dua kali musim panen.
Energi merupakan input penting berupa sumber tenaga (power source) dalam kegiatan pertanian di antaranya bahan bakar, listrik, mesin, bibit, pupuk dan bahan kimia lainnya yang digunakan. Input energi memiliki peran besar terhadap output energi dalam sistem pertanian modern maupun pertanian konvensional. Penggunaan sarana produksi pertanian dan energi fosil secara intensif berdampak pada peningkatan produksi pertanian (Hatirli, Ozkan dan Fert, 2006).

Beberapa penelitian audit energi telah dilakukan oleh beberapa peneliti dengan komoditas berbeda-beda seperti; 1) kentang di Provinsi Hamadan, Iran (Zangeneh et al., 2010), 2) mentimun di Iran (Mohammadi dan Omid, 2010), 3) tomat di Turki (Ozkan, et al., 2011), 4) padi di Malaysia (Bockari-Gevao et al., 2005 dan Muazu et al., 2015), dan 5) padi (Lubis et. al.,2019, 2019a dan 6) Putri, el. 
al., 2019b, 2019c) dan jagung Putri,et.al., (2020, 2020a,2020b).

Pemipilan jagung merupakan cara penanganan pascapanen yang membutuhkan perhatian. Kadar air jagung sekitar $18-20 \%$ dapat menjadi waktu yang tepat untuk melakukan pemipilan jagung. Dalam proses pasca panen jagung, proses pemipilan memiliki tingkat kehilangan hasil jagung hingga mencapai $4 \%$ sedangkan kehilangan hasil jagung pada keseluruhan proses sebesar 5,2\% (Sudjudi, 2004).

Proses pemipilan jagung dapat dilakukan denganicaraimanual, alat pemipil sederhana dan mekanis. Pemipilan jagung secara manual pada umumnya masih dilakukan oleh petani dengan menggunakan tangan. Keuntungan pemipilan jagung secara manual yaitu persentase biji yang tidak terpipil rendah dan memiliki sedikit kotoran (debu, kerikil dan dedak). Pemipilan jagung dengan bantuan alat sederhana umumnya terbuat dari kayu atau besi serta relatif masih membutuhkan waktu yang cukup lama dan tenaga yang besar. Pemipilan jagung secara mekanis sudah banyak digunakan oleh industri. Mesin pemipil menggunakan motor diesel sebagai tenaga penggeraknya. Jagung yang sudah dipanen oleh petani dapat langsung dipipil dengan menggunakan alat pemipil (corn sheller).

Mesin pemipil jagung (corn sheller) merupakan salah satu teknologi pemipilan jagung yang sangat berperan penting dalam proses penanganan pascapanen jagung. Beberapa peneliti melakukan kajian mesin pemipil jagung meliputi; Kobarsih et.al., (2019), Lisman et. al., (2019), Suparlan, et. al., (2018), Amrin, et. al., (2021). Setiaji, (2017), Hermawan dan Setiafindari (2021), Kurniawan (2018), Armanto et. al., (2021), Izzuddin (2019). Hampir dari semua penelitian yang ada hanya melakukan kajian teknis dari alat pemipil tersebut, tetapi analisa konsumsi energi yang dibutuhkan pada saat proses pemipilan masih belum dilakukan. Tujuan penelitian ini adalah untuk mengevaluasi total energi yang diperlukan selama proses pemipilan jagung dan melakukan uji teknis untuk masing-masing metode pemipilan jagung.

\section{METODOLOGI}

Penelitian dilakukan dengan metode eksperimen, perlakuan pada penelitian ini ada 3 metode pemipilan jagung yaitu: 1) manual, 2) alat pemipil sederhana, dan 3) mekanis. Pemipilan jagung secara manual menggunakan $80 \mathrm{~kg}$ jagung bertongkol untuk masing-masing pekerja. Pemipilan jagung alat pemipil sederhana menggunakan $80 \mathrm{~kg}$ jagung bertongkol, dan pemipilan secara mekanis menggunakan 80 $\mathrm{kg}$ jagung bertongkol. Masing-masing perlakuan diulang sebanyak tiga kali. Ketiga metode pemipilan jagung memiliki jenis jagung yang sama. Diagram Alir penelitian dapat dilihat pada Gambar 1, pemipilan manual dapat dilihat pada Gambar 2, pemipilan alat pemipil sederhana dapat dilihat pada Gambar 3, dan pemipilan secara mekanis dapat dilihat pada Gambar 4.

\section{Analisa input energi untuk proses pemipilan \\ 1. Manusia}

Pengukuran energi manusia dapat dilakukan dengan menggunakan garmin forerunner 35 dipasangkan pada pergelangan tangan dan HRM pada dada operator saat melakukan pemipilan jagung. Fungsi dari garmin forerunner 35 untuk menghitung kalori dan HRM untuk membaca detak jantung yang dihasilkan dalam bentuk grafik, waktu kerja, kecepatan kerja, total kalori operator dalam proses pemipilan.

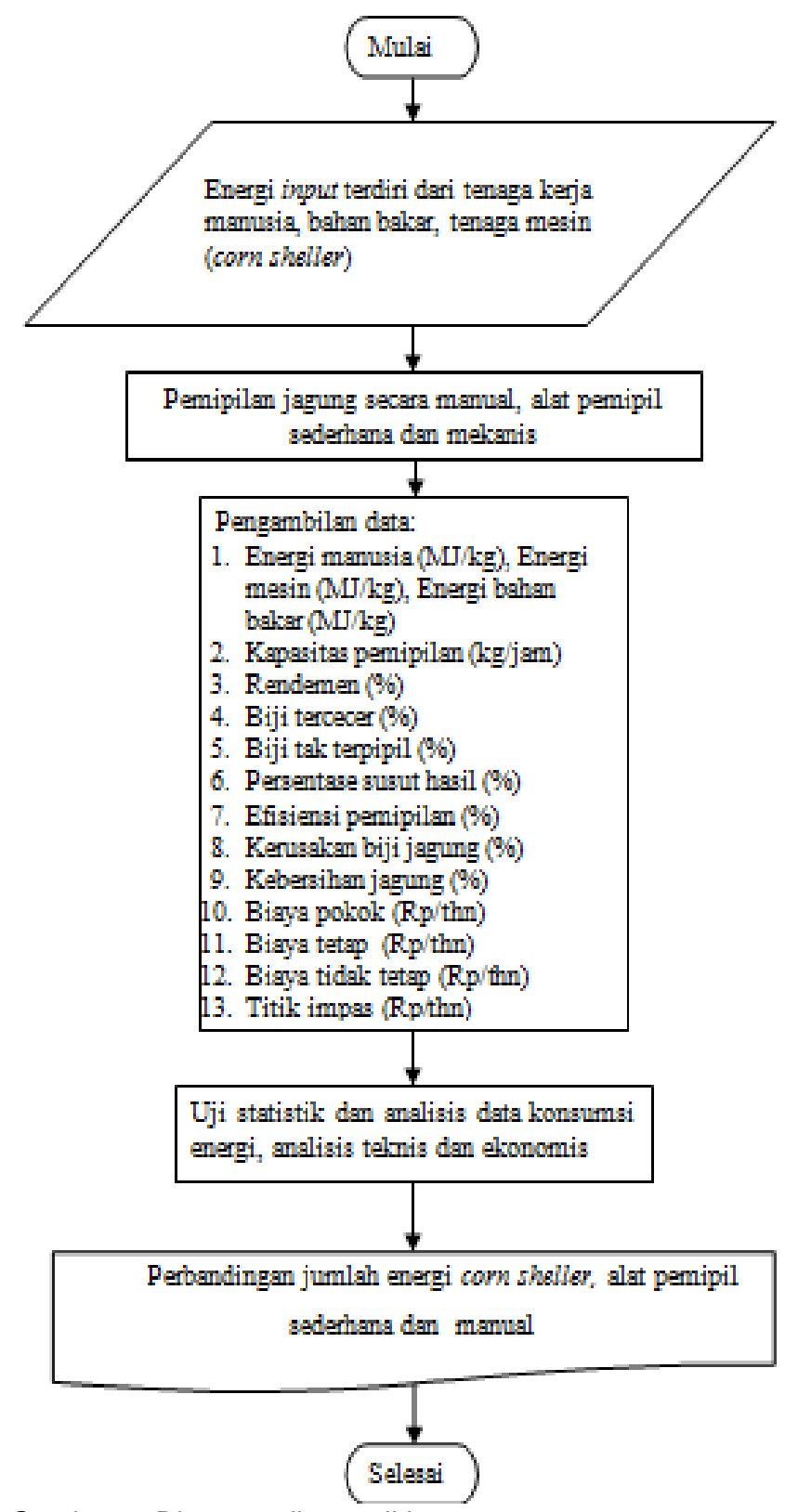

Gambar 1. Diagram alir penelitian

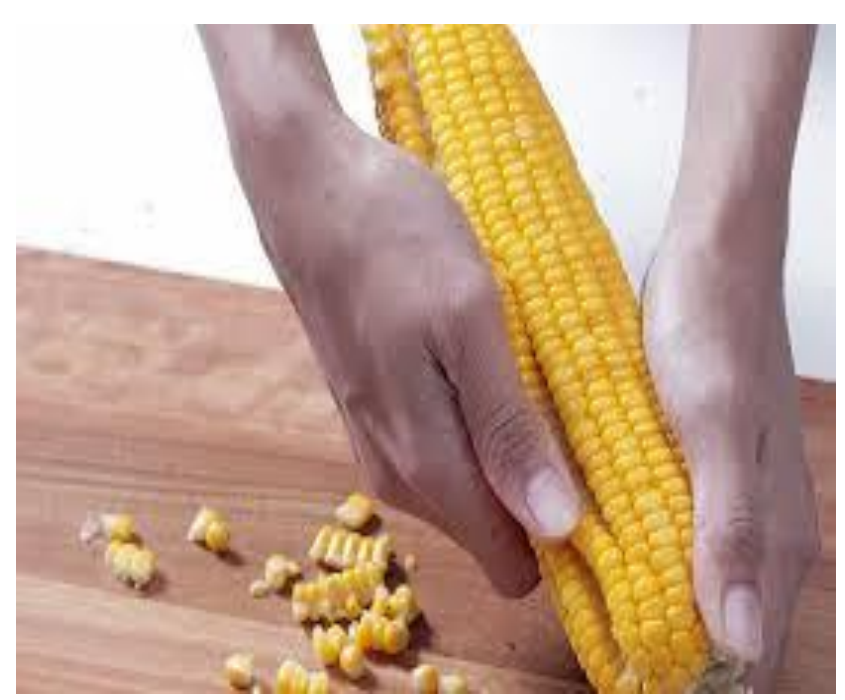

Gambar 2. Pemipilan secara manual 


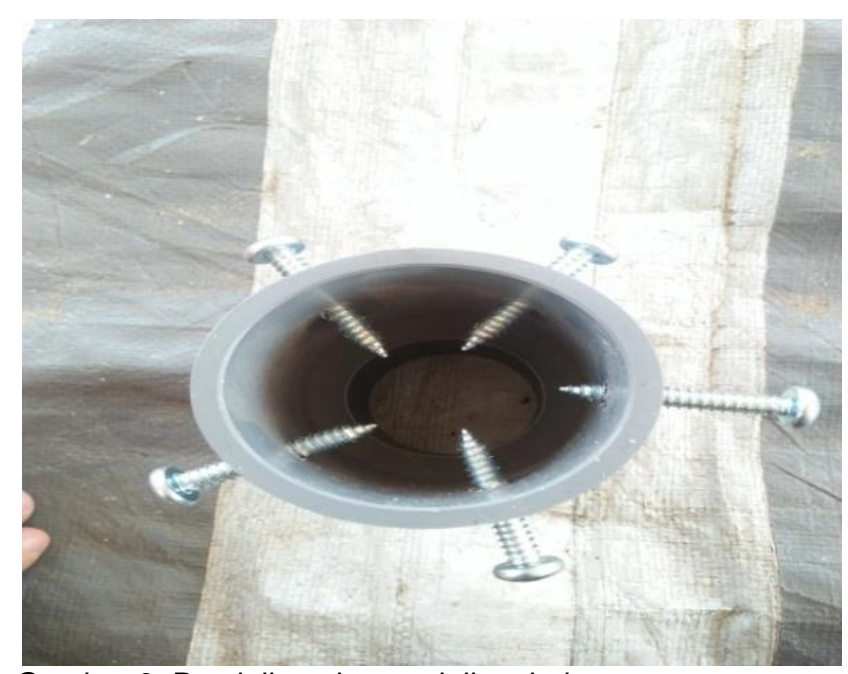

Gambar 3. Pemipilan alat pemipil sederhana

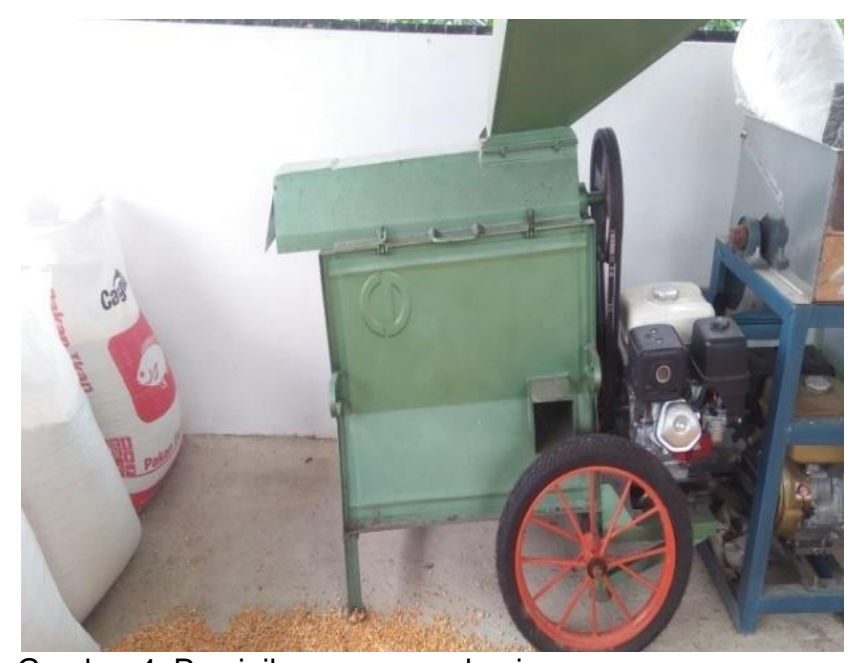

Gambar 4. Pemipilan secara mekanis

\section{Bahan bakar (Muazu, 2015)}

Pengukuran jumlah bahan bakar yang digunakan untuk mesin ditentukan langsung pada saat awal dilakukan pemipilan jagung. Energi bahan bakar yang digunakan mesin dapat dihitung dengan menggunakan persamaan 1:

$\mathrm{FE}=\frac{\mathrm{BK} \times \mathrm{fk}_{1}}{\mathrm{~J}}$.

Dimana:

FE : Energi bahan bakar $(\mathrm{MJ} / \mathrm{kg})$

BK : Bahan bakar yang dikonsumsi (liter)

$\mathrm{Fk}_{1} \quad$ : Faktor konversi energi bahan bakar (MJ/liter)

$\mathrm{J} \quad$ : Berat jagung $(\mathrm{kg})$

Koefisien konversi energi digunakan sebagai faktor konversi nilai energi. Koefisien energi yang digunakan meliputi koefisien energi bahan bakar ( $\left.\mathrm{fk}_{1}\right)$, dan koefisien energi mesin ( $\mathrm{fk}_{2}$ ). Nilai koefisien energi dapat dilihat pada Tabel 1.

Tabel 1. Koefisien Energi Pemipilan Jagung

\begin{tabular}{lll}
\hline \multicolumn{1}{c}{ Material } & \multicolumn{1}{c}{$\begin{array}{c}\text { Koefisien } \\
\text { Konversi }\end{array}$} & \multicolumn{1}{c}{ Sumber } \\
\hline Diesel oil / bensin & $56,31(\mathrm{MJ} / \mathrm{liter})$ & Ibrahim (2011) \\
Machine & $15,2(\mathrm{MJ} / \mathrm{kg})$ & Ibrahim (2011) \\
\hline
\end{tabular}

\section{Mesin (Muazu, 2015)}

Untuk menghitung energi mesin dapat dicari dengan menggunakan persamaan 2 sebagai berikut:
$\mathrm{ME}=\frac{\mathrm{fk}_{2} \times \mathrm{W}}{\mathrm{KKE} \times \mathrm{L}}$

Dimana:

ME : Energi mesin (MJ/kg)

$\mathrm{Fk}_{2}$ : Faktor konversi energi untuk mesin yang digunakan $(\mathrm{MJ} / \mathrm{kg})$

W : Berat mesin yang digunakan $(\mathrm{kg})$

KKE : Kapasitas lapang efektif $(\mathrm{kg} / \mathrm{jam})$

$\mathrm{L} \quad$ : Umur ekonomis mesin (jam)

\section{Uji teknis pemipilan}

\section{Kapasitas pemipilan}

Kapasitas kerja mesin pemipil jagung dapat dihitung dengan berat jagung yang dipipil, kemudian dihitung berapa waktu yang dibutuhkan sampai semua jagung selesai dipipil. Kapasitas mesin pemipil dapat dihitung dengan rumus persamaan 3 sebagai berikut:

$\mathrm{Kp}=\frac{\text { beratjagung }(\mathrm{kg})}{\text { waktu }(\mathrm{jam})}$.

Dimana:

$\mathrm{Kp}$ : Kapasitas pemipilan jagung ( $\mathrm{kg} / \mathrm{jam})$

\section{Rendemen pemipilan (R)}

Rendemen pemipilan jagung $(R)$ dapat ditentukan dengan menggunakan persamaan 4 :

$\mathrm{R}=\frac{\mathrm{Wp}}{\mathrm{Wo}_{1}} \times 100 \%$

Dimana:

R : Rendemen pemipilan jagung (\%)

Wp : Biji jagung hasil pemipilan $(\mathrm{kg})$

$\mathrm{Wo}_{1} \quad$ : Berat jagung bertongkol $(\mathrm{kg})$

\section{HASIL DAN PEMBAHASAN}

\section{Analisis input energi untuk proses pemipilan}

Analisis energi yang dilakukan pada penelitian ini meliputi analisis konsumsi energi mesin, analisis konsumsi energi bahan bakar dan energi manusia. Analisis konsumsi energi pemipilan jagung dilakukan dengan menggunakan tiga metode pemipilan jagung yang umum dilakukan masyarakat. Pemipilan jagung Padang Pariaman menggunakan metode sebagai berikut: (1) pemipilan jagung menggunakan Corn Sheller (mekanis); (2) pemipilan jagung semi mekanis; (3) pemipilan jagung menggunakan tangan (manual). Adapun distribusi energi input didapatkan dari kegiatan pemipilan jagung sebagai berikut:

\section{Energi manusia}

Energi manusia diukur menggunakan Garmin Forerunner 35 dan Heart Rate Monitor (HRM). Hasil pengukuran energi manusia menggunakan Garmin Forerunner 35 dan Heart Rate Monitor dapat dilihat pada Gambar 5. Rata-rata konsumsi energi manusia yang diperoleh sebesar 50,66 MJ/ton, 282,33 MJ/ton, 388,66 $\mathrm{MJ} /$ ton untuk masing-masing perlakuan proses pemipilan jagung secara mekanis, sederhana, dan manual. Menurut Mardalena (2019), pengukuran energi manusia diduga lebih tepat menggunakan garmin forerunner $35 . \mathrm{Hal}$ itu disebabkan karena pada garmin forerunner 35 dilakukan pengaturan umur operator, berat operator, tinggi operator, dan jenis kelamin operator, sehingga nilai energi yang diperoleh lebih akurat.

Berdasarkan grafik pada Gambar 5 dapat diketahui perbandingan dari ketiga metode pemipilan jagung yang telah dilakukan. Perbandingan antaran pemipilan mekanis, alat pemipil sederhana dan manual sangatlah signifikan. Konsumsi energi pemipilan alat pemipil sederhana lima kali 
lipat lebih besar dari nilai konsumsi energi mekanis. Perbandingan nilai konsumsi energi pemipilan alat pemipil sederhana dengan manual tidak terlalu signifikan atau tidak terlalu jauh. Setelah melakukan perhitungan total energi saat pemipilan jagung dengan tiga perlakuan maka dilakukan pengujian untuk melihat signifikan perbedaan energi yang dikeluarkan selam proses pemipilan jagung.

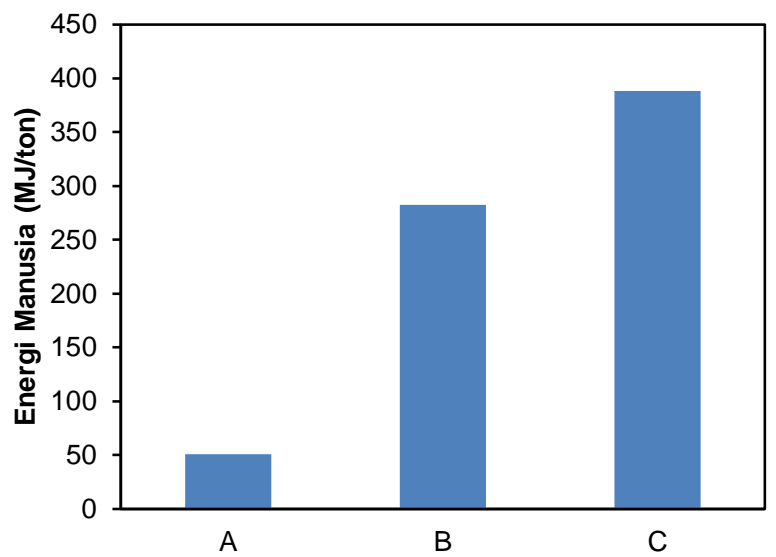

Gambar 5. Total Konsumsi Energi Manusia (A: Pemipilan secara mekanis, B: Pemipilan alat pemipil sederhana, C: Pemipilan jagung secara manual)

\section{Energi bahan bakar}

Bahan bakar dibutuhkan untuk menggerakkan alat pemipil jagung pada proses pemipilan dengan menggunakan corn sheller. Bahan bakar yang dibutuhkan corn sheller adalah bensin. Jumlah bahan bakar yang dihabiskan selama proses pemipilan jagung diketahui untuk mendapatkan nilai konsumsi bahan bakar. Konsumsi bahan bakar selama proses pemipilan jagung dipengaruhi oleh jumlah jagung yang dipipil karena semakin banyak jagung yang dipipil maka semakin banyak bahan bakar yang terpakai. Jumlah bahan bakar yang dihabiskan selama proses pemipilan jagung diketahui untuk mendapatkan nilai konsumsi bahan bakar. Rata-rata energi bahan bakar yang diperoleh pada saat pemipilan jagung yang dilakukan sebanyak tiga kali ulangan sebesar 253,39 MJ/ton, dengan penggunaan bahan bakar sebesar 1,05 liter/ton. Besar atau kecilnya bahan bakar dipengaruhi oleh konsumsi bahan bakar saat pemipilan.

\section{Energi mesin}

Jenis mesin yang digunakan pada proses pemipilan jagung secara mekanis adalah corn sheller. Rata-rata yang diperoleh pada energi mesin dengan tiga kali ulangan sebesar 0,18 MJ/ton. Energi mesin hanya didapatkan pada pemipilan mekanis. Pemipilan alat pemipil sederhana masih menggunakan tangan untuk mengoperasikan alat tersebut sedangkan pemipilan manual masih menggunakan tangan. Rata-rata yang diperoleh pada energi mesin dengan tiga kali ulangan sebesar 0,18 $\mathrm{MJ}$ /ton. Energi mesin yang diperoleh hanya pada pemipilan mekanis, sedangkan pada pemipilan alat pemipil sederhana dan manual tidak diperoleh energi mesinnya, karena pemipilan alat pemipil sederhana masih menggunakan tangan untuk mengoperasikan alat tersebut sedangkan pemipilan manual masih menggunakan tangan.

\section{Total konsumsi energi}

Total konsumsi energi pada proses pemipilan jagung yang telah dilakukan dapat dilihat pada Tabel 2 . Berdasarkan Tabel 2, total konsumsi energi yang paling tinggi terdapat pada perlakuan $C$ sebesar $388,66 \mathrm{MJ} /$ ton, perlakuan $B$ diperoleh sebesar $282,33 \mathrm{MJ} /$ ton sedangkan pada perlakuan A diperoleh total konsumsi energi sebesar 304,24 MJ/ton. Setelah melakukan perhitungan total energi saat pemipilan jagung dengan tiga perlakuan maka dilakukan pengujian untuk melihat signifikan perbedaan energi yang dikeluarkan selama proses pemipilan jagung.

Tabel 2. Total konsumsi energi

\begin{tabular}{lccc}
\hline $\begin{array}{l}\text { Konsumsi } \\
\text { energi }\end{array}$ & A & B & C \\
\hline $\begin{array}{l}\text { Energi mesin } \\
\text { (MJ/ton) }\end{array}$ & 0,18 & - & - \\
$\begin{array}{l}\text { Energi bahan } \\
\text { bakar (MJ/ton) }\end{array}$ & 253,39 & - & - \\
$\begin{array}{l}\text { Energi manusia } \\
\text { (MJ/ton) }\end{array}$ & 50,66 & 282,33 & 388,66 \\
\hline Total & $\mathbf{3 0 4 , 2 4}$ & $\mathbf{2 8 2 , 3 3}$ & $\mathbf{3 8 8 , 6 6}$ \\
\hline
\end{tabular}

Keterangan tabel: A: Pemipilan secara mekanis, B: Pemipilan alat pemipil sederhana, C: Pemipilan jagung secara manual

\section{Uji teknis pemipilan}

\section{Kapasitas pemipilan jagung}

Kapasitas pemipilan jagung ditentukan oleh banyaknya jagung yang dihasilkan dari proses pemipilan persatuan waktu. Laju pemasukan bahan, kecepatan poros, dan daya yang tersedia pada mesin mempengaruhi besarnya kapasitas kerja mesin. Fisik dan kualitas dari alat mempengaruhi kapasitas kerja alat. Keterampilan operator dalam mengoperasikan alat menjadi pengaruh lain dalam kapasitas kerja pemipilan. Cara pemipilan berpengaruh secara nyata terhadap kapasitas pemipilan, baik itu kapasitas pemipilan mekanis, alat pemipil sederhana dan manual.. Pemipilan jagung secara manual atau menggunakan tangan berlangsung dengan kecepatan rendah dan membosankan pekerja. Perbandingan nilai kapasitas antara pemipilan mekanis, alat pemipil sederhana dan manual dapat dilihat juga pada Gambar 6 .

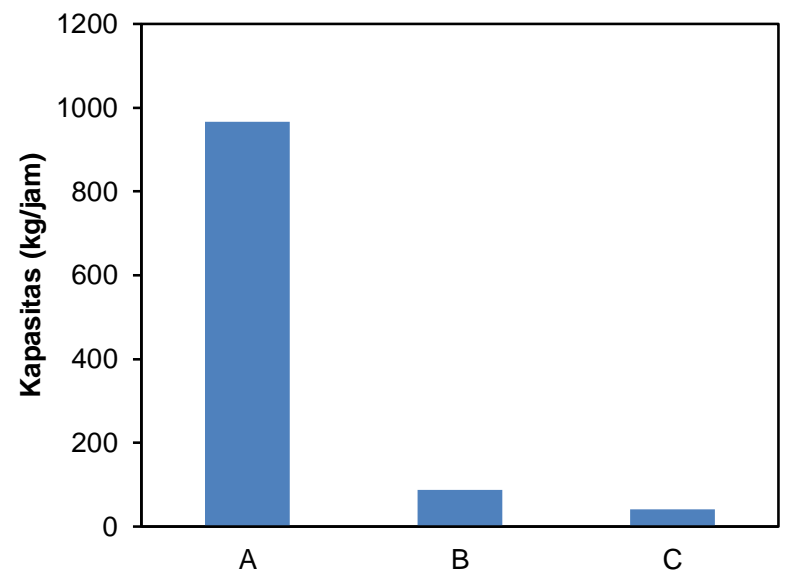

Gambar 6. Perbandingan Nilai Kapasitas Pemipilan Jagung Pada Berbagai Metode Pemipilan (A: Pemipilan secara mekanis, B: Pemipilan alat pemipil sederhana, C: Pemipilan jagung secara manual)

Berdasarkan grafik perbandingan kapasitas pemipilan yang terdapat pada gambar 6 dapat dilihat nilai kapasitas dari ketiga perlakuan yang berbeda secara signifikan. Kapasitas pemipilan jagung secara mekanis, alat pemipil sederhana dan manual sebesar 908,06 kg/jam, $87,93 \mathrm{~kg} / \mathrm{jam}$ dan 40,65 kg/jam. Menurut Mardalena (2019), dari hasil penelitian yang telah dilakukan dengan menggunakan penggiling gabah statis dan dinamis menyatakan bahwa kapasitas pemipilan akan semakin besar apabila waktu yang digunakan pada saat pemipilan semakin lama, tetapi berdasarkan hasil yang telah diperoleh seperti yang terdapat pada Gambar 6 bahwa pemipilan jagung 
secara mekanis lebih besar kapasitasnya dibandingkan dengan pemipilan alat pemipil sederhana dan manual sedangkan waktu pemipilan alat pemipil sederhana dan manual lebih lama dibandingkan dengan pemipilan secara mekanis.

Berdasarkan penelitian yang dilakukan oleh Fajri (2019), nilai kapasitas yang diperoleh sebesar 201,87 kg/jam untuk mekanis, $62,48 \mathrm{~kg} / \mathrm{jam}$ untuk alat pemipil sederhana dan 24,90 kg/jam untuk manual. Nilai kapasitas untuk pemipilan mekanis, alat pemipil sederhana dan manual yang diperoleh dari penelitian lebih besar dibandingkan hasil penelitian yang dilakukan oleh Fajri (2019). Apabila kapasitas yang diperoleh besar maka rendemen pemipilan yang didapatkan kecil. Nilai kapasitas yang diperoleh pada pemipilan mekanis dan alat pemipil sederhana lebih besar dibandingkan nilai rendemennya, sedangkan nilai kapasitas pemipilan manual yang diperoleh lebih kecil dibandingkan dengan rendemennya.

\section{Rendemen pemipilan jagung}

Rendemen pemipilan jagung adalah persentase antara banyaknya jagung yang dihasilkan pada saat pemipilan dibagi dengan banyaknya jagung dipipil. Berdasarkan penelitian yang telah dilakukan didapatkan nilai rendemen yang berbeda-beda pada masing-masing perlakuan. Grafik perbandingan rendemen pemipilan jagung dapat dilihat pada Gambar 7.

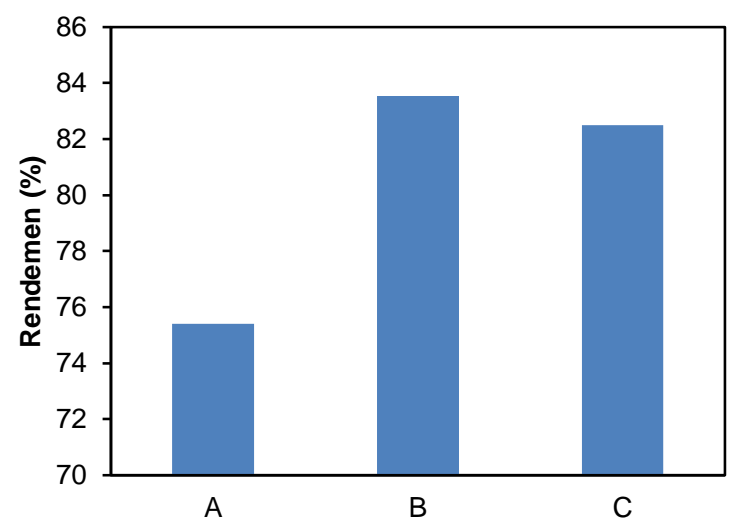

Gambar 7. Perbandingan rendemen pemipilan mekanis, alat pemipil sederhana dan manual (A: Pemipilan secara mekanis, B: Pemipilan alat pemipil sederhana, C: Pemipilan jagung secara manual).

Rata-rata rendemen pada pemipilan jagung mekanis sebesar $75,41 \%$, rata-rata rendemen alat pemipil sederhana sebesar $83,54 \%$ dan rata-rata rendemen manual sebesar $82,50 \%$. Perbedaan nilai rendemen ini diakibatkan karena saat pemipilan secara manual dan sederhana hasil pemipilan dapat ditampung secara sempurna sehingga berat akhir yang dihasilkan lebih banyak. Berbeda dengan mekanis, hasil pemipilan ada yang hancur karena penggunakan alat dan ada juga terlempar dari corong keluaran alat.

Rendemen pemipilan semi mekanis lebih besar dibandingkan dengan rendemen manual tetapi tidak terlalu berbeda secara signifikan, sedangkan pemipilan mekanis berbeda secara signifikan dengan pemipilan alat pemipil sederhana dan manual. Perbandingan rendemen pemipilan juga dapat dilihat pada grafik yang terdapat pada Gambar 7 . Rendemen sangat penting diketahui untuk mendapatkan gambaran seberapa besar suatu produk untuk dapat dimanfaatkan dengan baik dan nilai ekonomis produk tersebut, semakin tinggi rendemen suatu produk maka semakin tinggi pula nilai ekonomis yang dimiliki (Lopulalan, et al., 2008) Berdasarkan penelitian yang telah dilakukan oleh Fajri (2019), nilai rendemen yang diperoleh pada pemipilan mekanis, alat pemipil sederhana dan manual sebesar $64,99 \%, 75,06 \%$ dan 84,97\%. Hasil yang diperoleh pada saat penelitian berbeda dengan hasil yang diperoleh oleh Fajri pada saat melakukan penelitian pada tahun 2019 silam.

\section{KESIMPULAN}

Berdasarkan data penelitian yang telah didapatkan, maka dapat disimpulkan bahwa rata-rata konsumsi energi pemipilan jagung menggunakan garmin forerunner 35 secara mekanis, alat pemipil sederhana dan manual sebesar $50,66 \mathrm{MJ} /$ ton mekanis, 282,33 MJ/ton pemipilan alat pemipil sederhana dan $388,66 \mathrm{MJ} /$ ton untuk pemipilan secara manual. Kapasitas pemipilan jagung secara mekanis, alat pemipil sederhana dan manual sebesar 908,06 kg/jam, $87,93 \mathrm{~kg} / \mathrm{jam}$ dan $40,65 \mathrm{~kg} / \mathrm{jam}$. rendemen pemipilan jagung diperoleh sebesar $75,41 \%$ mekanis, 83,54 alat pemipil sederhana dan 82,50 manual. Data ini dapat dijadikan acuan dapat mendesain alat pemipil lainnya. Disarankan kepada masyarakat untuk melakukan pemipilan jagung meggunakan mesin pemipil jagung saja karena lebih efektif dan efisien dari segi waktu, tenaga dan lain sebagainnya dibandingkan dengan pemipilan menggunakan tangan atau secara manual dan alat sederhana.

\section{DAFTAR PUSTAKA}

Amrin, H., Jamaluddi, J., \& Lahming, L. 2021. Rancang Bangun Alat Pemipil Jagung Semi Mekanis. Jurnal Pendidikan Teknologi Pertanian, 5(2), 25-30.

Armanto, E., Carli, C., Hartono, H., Daryadi, D., Wattimena, R. M., \& Sunarto, S. 2021. Alat Perontok Jagung Bagi Kelompok Petani Desa Prigi Kecamatan Kedungjati Kabupaten Grobogan. In Prosiding Seminar Hasil Penelitian dan Pengabdian Masyarakat (Vol. 3, No. 1).

Badan Pusat Statistik. 2020. Luas Panen, Produksi, dan Produktivitas Jagung 2015-2017. URL https://sumbar.bps.go.id/

Bockari-gevao, S. M., W. Ishak., dan A. Yahya. 2005. Analysis of Energy Consumption in Lowland RiceBased Cropping System of Malaysia.Songklanakarin J. Science Technology(27): 819-826.

Fajri, M. Kobarsih, M. Apriyani, E., dan Sulasmi. 2019. Kajian Teknik Pemipilan Jagung Di Dusun Pakis, Dlingo, Bantul, DI Yogyakarta. Balai Pengkajian Teknologi Yogyakarta.

Hatirli, S.A., Ozkan, B. dan Fert, C. 2006. Energy Inputs and Crop Yield Relationship in Greenhouse Tomato Production. Renewable Energy 31:427438.

Hermawan, R., \& Setiafindari, W. 2021. Perancangan Alat Pemipil Jagung Dengan Metode Quality Function Deployment (Doctoral dissertation, University of Technology Yogyakarta).

Izzuddin, A. 2019. Rancang Bangun Mesin Pemipil Jagung Kapasitas $350 \mathrm{~kg} / \mathrm{jam}$ Berpenggerak Motor Bensin (Doctoral dissertation, Vokasi undip).

Kobarsih, M., Purwaningsih, P., Apriyati, E., Sulasmi, S., Djaafar, T. F., \& Indrasari, S. D. 2019. Kajian Teknik Pemipilan Jagung di Dusun Pakis, Dlingo, Bantul, DI Yogyakarta. In Prosiding Seminar Nasional Fakultas Pertanian UNS (Vol. 3, No. 1, pp. A-14).

Kurniawan, M., Pomalingo, M. F., \& Ginting, A. S. 2018. Desain Komponen Pemipil Jagung Pada Mesin Perontok Pajaka (Padi, Jagung, Kacang). Jurnal Teknologi Pertanian Gorontalo (JTPG), 3(2), 78-81. 
Lisman, F., Syahriza, R., Nurtam, M. R., \& Djinis, M. E. 2019. Rancang Bangun Alat Pemipil Jagung Sederhana. Agroteknika, 2(1), 11-19.

Lopulalan C.G.C, Sugiyono, Haryanto B. 2008. (dalam Iswandi 2017). Kajian Formulasi Biskuit Jagung Dalam Rangka Substitusi Tepung Terigu. Jurnal Teknol Industri Pangan $20: 32-40$.

Lubis, M. I. A., Putri, R. E., Hasan, A., Arlius, F., \& Santosa, S. 2019a. Evaluasi Kinerja dan Energi pada Aktivitas Penyemprotan Padi di Sumatera Barat. Rona Teknik Pertanian, 12 (2), 49-57.

Lubis, M. I. A., Putri, R. E., Arlius, F., \& Hasan, A. 2019. Energy Consumption on Tillage Operation in Low Land Paddy Cultivation. In IOP Conference Series: Earth and Environmental Science (Vol. 327, No. 1, p. 012010). IOP Publishing.

Mardalena, Liza. 2019. Studi Konsumsi Energi Penggilingan Gabah pada Rice Milling Unit (RMU). Padang: Universitas Andalas.

Mohammadi, A. dan Omid, M. 2010. Economical analysis and relation between energy inputs and yield of greenhouse cucumber production in Iran. Applied Energy. Elsevier Ltd, 87 (1): 191-196

Muatzu, Ishak, Bejo. 2015. energy audit of sustain ablewetl and paddy cultivation in malaysia. Department of biological and agriculture enginering. Faculty of engineering . Serdang. University Putra Malaysia.

Ozkan, B., Ceylan, R. F., dan Kizilay, H. 2011. Comparison of Energy Inputs in Glasshouse Double Crop ( Fall and Summer Crops ) Tomato Production.Renewable

Putri, R. E., Andasuryani, A., \& Mardalena, L. (2019c). Analisis Perbandingan Konsumsi Energi Penggilinggan Gabah Pada Rice Milling Unit (Rmu) Statis Dan Dinamis. Jurnal Teknologi Pertanian, 8(1), 29-37.

Putri, R. E., Cahyani, G. A., Fahmy, K., Arlius, F., \& Hasan, A. 2020a. Comparison of Performance and Total Energy Requirement for Several Harvesting Method of Indonesian Farmers. In IOP Conference Series: Earth and Environmental Science (Vol. 515, No. 1, p. 012004). IOP Publishing.

Putri, R. E., Fadhilah, R., \& Cherie, D. 2019b. Studi Perbandingan Konsumsi Energi Pada Proses Penanaman Padi Manual Dan Rice Transplanter. Jurnal Teknologi Pertanian Andalas, 23(2), 125-135.

Putri, R. E., Fadhilah, R., Cherie, D., \& Novianda, A. W. 2020c. Analysis of Energy Consumption and Performance Test on Rice Planting Using Rice Transplanter: A Case Study in West Sumatera Province, Indonesia. Journal of Applied Agricultural Science and Technology, 4(1), 12-25.

Putri, R. E., Lovena, C., \& Fahmy, K. 2020b. Studi Kasus Audit Energi Pada Budi Daya Jagung Sumatera Barat. Jurnal Teknologi Pertanian Andalas, 24(1), 5466.

Setiaji, M. A. L. 2017. Perencanaan dan perhitungan Mesin Pemipil Jagung dengan Kapasitas 300 $\mathrm{kg} / \mathrm{jam}$. Fakultas Teknik Universitas Nusantara PGRI Kediri.

Suparlan, S., Marsudi, M., \& Budiharti, U. 2018. Evaluasi Teknis dan Ekonomis Mesin Pemipil Jagung Berkelobot. Jurnal Keteknikan Pertanian, 6(2), 225232.

Sudjudi. 2004. Alat pemipil jagung mudah dan murah. Balai Pengkajian Teknologi Pertanian. Nusa Tenggara Barat.

Zangeneh, M., Omid, M. dan Akram, A. 2010. A Comparative Study on Energy Use and Cost Analysis of Potato Production Under Different Farming Technologies in Hamadan Province of Iran. Energy35(7): 29272933 